\title{
Introduction
}

To write an introduction for two articles dealing with such different topics may appear contrived. At first glance, this is true: one describes the rare disease of bone mineralization and the other presents an extensive picture of very unusual cases of diabetes occurring during the neonatal period.

But in fact these articles by Drs. Van Hul and Hamilton-Shield illustrate the power of molecular biology when applied to a series of rare cases with a reasonable homogeneous phenotype. In some instances, genomic analysis can shed light on the role of known genes; in others, new genes could be discovered, which may help in understanding new mechanisms. Some of these rare diseases are recessive disorders; it is equally possible that heterozygosity could have clinical although subtle consequences and play a role in the expression of disease. This should also be studied carefully.

This work is the result of the careful collaboration of dedicated clinicians and experts in molecular biology. To say that this collaboration has been fertile is a banality; however, we are convinced that the fantastic power of modern molecular biology together with precise observations made by clinicians will bring about many new discoveries.

\section{Disclosure Statement}

The author declares a relevant financial relationship with a commercial interest. The author has received consulting fees from Pfizer and is an independent contractor and an advisory committee member of Pfizer.

\section{Paul Czernichow}

Paediatric Department

Hôpital Robert Debré

Paris, France

\section{KARGER}

Fax +4161306 1234

E-Mail karger@karger.ch

www.karger.com
(C) 2007 S. Karger AG, Basel

0301-0163/07/2811-0031\$23.50/0

Accessible online at: www.karger.com/hre
Paul Czernichow

Hôpital des Enfants Malades

FR-75019 Paris (France)

Tel. +33 674293 814, Fax +33 140031987

E-Mail paul.czernichow@rdb.ap-hop-paris.fr 